\title{
Democracy, Human Development, and Happiness Indices as Precursors of International Student Success
}

\author{
Ayse Ottekin Demirbolat ${ }^{1}$ \\ ${ }^{1}$ Department of Educational Administration, Gazi University, Ankara, Turkey \\ Correspondence: Ayşe Ottekin Demirbolat, Department of Educational Administration, Gazi University, Ankara, \\ Turkey. E-mail: ademir@gazi.edu.tr
}

Received: October 24, 2017

Accepted: November 22, 2017 Online Published: December 20, 2017

doi: $10.5539 /$ jel.v7n1p237

URL: https://doi.org/10.5539/jel.v7n1p237

\begin{abstract}
This paper aims to explore the relationships between educational attainment as expressed in PISA scores and several socio-economic and political variables some of which are sub-indices of Human Development Index. The correlation analysis reveals that there are highly significant associations between educational attainment and civil liberties, political participation, GDP per capita, average years of schooling, expected years of schooling and happiness. However, of these, regression analysis indicates that only expected years of schooling and average years of schooling appear as predictors of educational attainment. The lack of explanatory power of political participation, happiness and civil liberties variables may possibly be due to the inclusion of hard to measure subjective factors in the definition of these, which may not reflect the true state of affairs.
\end{abstract}

Keywords: educational attainment, human development, reading skills

\section{Introduction}

\subsection{Introduce the Problem}

International student assessments provide important findings as regards the educational systems of nations but they fail to present a clear understanding of the national realities that affect these outcomes. Using indices, some of which are sub-indices of human development index, this paper aims to explore the relationship between some of these national realities such as political participation, civil liberties, level of happiness, per capita income and educational achievement.

There are not a few studies in the relevant literature as regards the effect of education on such social realities as democracy, economic development, human development, and happiness, and on the interaction of these with each other; however, only a few that investigate the effect of those social realities on success in education. In fact, the relations between social realities and education are not uni but bidirectional. There is as much possibility of education affecting, democratic, economic and human development, and social happiness, as these affecting education both in quality and in quantity.

Reflections in modern times on the relation between democracy and education started with Alexis de Tocqueville (1848) and continued with John Dewey (1916), and others who generally thought that education was a prerequisite for democracy. This view was also supported by the modernisation theory of Seymour Martin Lipset (1959), which posited that economic development and education are prerequisites of democracy. Education prevents people from getting stuck with narrow, ortodox doctrines and increases their capacity to think rationally and to make logical choices (Lipset, 1959). Experimental studies that explored the positive relation between the level of education and democratic policies (Barro, 1999; Glaeser, La Porta, Lopez, Florencio \& Shleifer, 2004; Glaeser, Ponzetto, \& Sheifer 2006; Papaioannou \& Siourounis, 2008) concluded that reading, writing, comprehension, and communication skills acquired at schools positively affected the political participation processes. Referring to the role of social environment in democracies, Weber (1930) and Huntington (1993) posited that culture, social divisions (ethnic, religious, and political polarisation), and political liberties would affect democracy more than education and income. Similarly Acemoğlu, Johnson, Robinson, \& Yared (2005) observed that investigations on the democracy-education relations would not always render similar results and that in order for democracy-education relation to be satisfactorily measured, conditions that might 
change periodically, should be taken into consideration for satisfactory assessment of the relationship (Acemoğlu, et al., 2005).

A number of studies focused on the relations between economic development and education. Porter (1990) advanced the view that education accelerated economic activity and civic adaptation. Giddens (2000) asserted that by changing technology and improving production methods, education contributed to the domestic economy's performance in the world markets. Varsakelis (2006) reflected that investments in education not only expanded the pool of qualified human resources, but also had positive impact on economic development by increasing social demands towards equality. Omoniyi (2013) maintained that education increased intellectual flexibility along with general productivity. Varsakelis (2006) asserted that quality of education together with the effectiveness of political institutions is of prime importance in generating innovative activity which is so important to the economy. Addressing the same issue, Adedeji \& Bamidele (2003) drew attention to the importance of the content of education, access to it, and matching education, especially the university education, with the demands of the labour market). Education also helps to decrease income inequality (Bourguignon, 2005; Psacharopoulos, 1998), and fertility rates (Wolfe, 1997).

The example of Vietnam demonstrates the relationships between the several variables mentioned above in concrete form. Vietnam launched comprehensive economic reforms during the late 1980s and shifted from planned to market economy. Fast economic development followed the political and economic reforms. In 1998s, GDP increased by $6 \%$ annually, consumption expenditure by $7 \%$, student enrolment at secondary schools by $6 \%$, and registration at high schools by $8 \%$. The example of Vietnam is important in that it shows that economic growth and human capital formation are mutually supporting (Glewwe \& Jacoby, 2004). In a similar vein to the studies on the relations between education and development, a number of studies have focused on the relations between development and democracy. While Lipset (1959) conjectured that there was a positive relation between democracy and economic development, Rustow (1970) and Lijphart (1975) asserted that economy did not figure as a dominant factor among the prerequisites of democracy. For Lijphart, what is important are the division of power and arrangements and regulations aiming at social consensus. Naturally, the political elites are the most important actors of this process.

Political participation also affects education, sometimes negatively. Studies performed in the USA and Swiss cantons illustrate that government financial decisions made in line with the people's demands transmitted through democratic processes may impact education in undesired ways. Cutting local tax rates, through propositions which in turn leads to decrease in public spending on education which negatively impacts quality of education and students' success (Fischer, 2007).

Along with the views claiming that economic factors do not have a dominant effect on democracy, there are others advancing the opposite view. For example Omoniyi (2013) maintains that the quality of investments substantially depend on the general political climate of a country. Roskin (2007) observes that knowledge generation and R\&D activities are limited in oppressive regimes. He associates China importing rather than producing technology with its oppressive political climate, and asserts that oppressive political cultures are not generative of new inventions and new ideas.

At this point, it is well to remember that there is also a close relationship between the quality of policy makers and their education level. Many developing countries have not been able to develop a knowledge based development strategy in part because their policy makers are either not able to diagnose the fundamental problems of their economies or, due to lack of education on their part, design proper strategies to overcome them even when the problems are correctly identified. Furthermore, lack of education of the policy makers and their narrow worldviews may restrict democratization process. Hence, it can be argued that democratization process is not a mono but a multi-faceted one (Papaioannou \& Siourounis, 2008).

Besides those exploring the connection between democracy and education, there are studies investigating the income, education and happiness link. This has long been the turf of psychologists and sociologists. Economists joined the band since Easterlin (1974). Easterlin claimed that there was no difference in the mean level of happiness of people living in rich and poor countries and that economic conditions were not effective in increasing the level of happiness. Recent studies by Frey \& Stutzer (2002) and Blanchflower \& Oswald (2004) confirm the findings of Easterlin. Further, controlling for other factors it was found that GDP per capita has little effect on the life satisfaction of individuals.

While income does not seem to affect the level of happiness, education does, both directly and indirectly. The direct effects of education on the well-being of individuals are manifest in such traits as self-confidence, 
self-esteem, and enjoyment of acquisition of knowledge, and its indirect effects in such issues as employment options, better quality job, better salary expectation, and better health conditions.

\subsection{Objectives of the Study}

The present study aims to explore the relations between democracy, human development, happiness and student performance using indices and to identify the predictive power of basic social contexts as expressed in sub-indices of political participation, civil liberties and happiness in determining academic success.

\section{Method}

\subsection{Research Design}

It Relational screening models are considered appropriate for exploring the existence and degree of covariance among two and more variables (Karasar, 2006). Hence, this model was adopted to explore the power of the levels of democracy, human development, and happiness indices of nations in predicting student performance levels.

\subsection{Sampling}

The population of the study consists of the countries listed in the international indices of Democracy (2015), Human Development (2016), World Happiness (2017), and Programme for International Student Assessment (PISA) (2015). The number of countries were 72 in the Programme for International Student Assessment (2015), the measurement tool of the research, 167 in the Democracy Index (2015), 188 in the Human Development Index (2016), and 126 countries in World Happiness Index (2017). There are 67 countries common to all the indices, and hence these constitute the research sample (Appendix A).

\subsection{Data Collection Tools}

Four international indices that contained 2015 data were used as data collection tools: Democracy Index (The Economist Intelligence Unit Limited, 2016), Human Development Report (UNDP, 2016), World Happiness Report (Helliwell, Layard, \& Sachs, 2017), and Programme for International Student Assessment (PISA) [OECD, 2016]. The Democracy Index has five sub-domains including electoral process and pluralism, functioning of government, political participation, political culture, and civil liberties. Human Development Index has four sub-domains: life expectancy at birth, expected years of schooling, average years of schooling, and gross domestic product (GDP) per capita. The World Happiness Index has six sub-domains: GDP per capita, average life expectancy, social support, trust, perception of liberties and generosity. Programme for International Student Assessment (PISA, 2015) encompasses three sub-domains of reading ability, mathematics, and science literacy. In as much as different indices included common or similar sub-domains, a selection was made among sub-domains and only seven were included: political participation, civil liberties, expected years all schooling, average years of schooling, capital GDP per capita, total value for happiness, and reading skills.

\subsection{Data Analysis}

Data analyses were performed using SPSS software package. First, research data obtained from the international indices were electronically transferred to the software. Second, outliers in the data set were removed and wrongly entered or incomplete values were adjusted. Finally, the data were analyses in accordance with the sub-problems of the research.

In multiple regression analyses a problem defined as multi-collinearity may be experienced between the predictive variables. Multi-collinearity denotes high level of relations among the independent variables. According to Field (2005), a highest Variance Infilation Factor (VIF) value of less than 10 and a tolerance value of above 20 is an indication that there is no multi-collinearity problem. A review of the VIF values obtained in the analysis [political participation (1.99), civil liberties (1.88), expected years of schooling (2.16), average years of schooling (1.94), GDP per capita (1.73), and happiness (2.03)] and the tolerance values [political participation (.50), civil liberties (.53), expected years of schooling (.46), average years of schooling (.52), and GDP (.58), and happiness (.49)] indicated no multi-collinearity problem. The skewness, kurtosis and the Kolmogorov-Smirnov values indicated that the distributions were normal.

Pearson product-moment correlation coefficient ( $r$ ) was used to identify the relations between the variables. Multiple Linear Regression Analysis was performed in order to find the predictive power of the independent variables for the dependent variable. Standardized Beta $(\beta)$ coefficients the t-test results for significance were the bases of in interpretation of the regression results. 


\section{Results}

The relation analysis findings between the independent and dependent variables of the research are provided in Table 1.

Table 1. Correlation between the variables

\begin{tabular}{|c|c|c|c|c|c|c|c|}
\hline Variables & 1 & 2 & 3 & 4 & 5 & 6 & 7 \\
\hline Political participation & 1.00 & $.59^{*}$ & $.59^{*}$ & $.49^{*}$ & .10 & $.46^{*}$ & $.38^{*}$ \\
\hline Civil liberties & & 1.00 & $.57^{*}$ & $50^{*}$ & .13 & $.45^{*}$ & $.41^{*}$ \\
\hline $\begin{array}{l}\text { Expected years } \\
\text { schooling }\end{array}$ & of & & 1.00 & $.58^{*}$ & $.31^{*}$ & $.55^{*}$ & $.69^{*}$ \\
\hline $\begin{array}{l}\text { Average years } \\
\text { schooling }\end{array}$ & of & & & 1.00 & $.44^{*}$ & $.43^{*}$ & $.68^{*}$ \\
\hline $\mathrm{GDP}^{* *}$ per capita & & & & & 1.00 & $.53^{*}$ & $.43^{*}$ \\
\hline Happiness & & & & & & 1.00 & $.49^{*}$ \\
\hline PISA-Reading Skill & & & & & & & 1.00 \\
\hline
\end{tabular}

There are positive and significant relations between PISA Reading Skills and the other variables. The highest association of the PISA Reading Skills with the expected years of schooling $(\mathrm{r}=.69, p \leq .01)$ and the next highest is between the average years of schooling $(\mathrm{r}=.68, p \leq .01)$.

Table 2. The results of the multiple regression analysis

\begin{tabular}{|c|c|c|c|c|c|c|}
\hline \multirow{2}{*}{ Variable } & & \multicolumn{5}{|c|}{ PISA-Reading Skills } \\
\hline & & $\mathrm{B}$ & Standard Error ${ }_{B}$ & $\beta$ & $t$ & $p$ \\
\hline \multirow[t]{4}{*}{ Constant } & & 133.03 & 42.05 & - & 3.16 & .00 \\
\hline & Political participation & -4.16 & 3.49 & -.13 & -1.19 & .24 \\
\hline & Civil liberties & -1.08 & 2.58 & -.05 & -.42 & .68 \\
\hline & Expected years of & 12.96 & 3.18 & .48 & 4.08 & .00 \\
\hline \multirow{3}{*}{$\begin{array}{l}\text { schooling } \\
\text { schooling }\end{array}$} & Average years of & 11.44 & 3.04 & .42 & 3.77 & .00 \\
\hline & GDP per capita & .18 & .26 & .07 & .70 & .49 \\
\hline & Happiness & 5.49 & 6.75 & .09 & .81 & .42 \\
\hline
\end{tabular}

Note. $\mathrm{R}=.79, \mathrm{R}^{2}=.62, \mathrm{~F}(6-60)=16.29, p \leq .01$.

The results of the regression analysis are given in Table 2 . The regression has high predictive power $(\mathrm{R}=.79$, $\left.\mathrm{R}^{2}=.62, p \leq .01\right)$. The six independent variables in combination account for $62 \%$ of the total variance in PISA Reading Skills scores.

However, the $t$-test on the significance of regression coefficients indicates that only the expected years of schooling and average years of schooling are significant predictors of the PISA Reading Skills scores.

\section{Discussion}

The purpose of the present study was to explore the relation between democracy (political participation, civil liberties), human development (expected years of schooling, average years of schooling, GDP per capita), and happiness and the international student performance assessment using indices for the variables.

The Correlation Matrix shows that there are positive and significant associations between PISA Reading Skills and all the independent variables, as can be observed in Table 1. The PISA Reading Skill scores of students will increase as a nation's level of democracy, human development, and happiness increase. This result is consistent with the expectations. Nevertheless, it is thought provoking that such social variables as political participation and civil liberties, which mostly affect the life experience of adults also seem to have an effect on the success of 15 -years-old students. However, when it is considered that social peace, social welfare, and social happiness, which partly ensure from civil liberties and political participation, have a direct effect on children through their families. It is the families which provide the first environment for learning and it is they which orient children and provide the necessary resources for their education (Omoniyi, 2013). 
Contrary to expectation's engendered by the discussion in the introduction and in relation to the correlation matrix, the regression analysis reveals that only two variables, average and expected years of schooling, appear as the predictors of reading skills. Especially important is the significant effect of expected years of schooling. This is because lower level of expected years of schooling may limit the future educational goals of the students and prevent them from focusing on success. Similarly the lower average years of schooling is indicative of the low importance attached to and low interest shown in education by the relevant society. This is no surprise as social and individual goals, and expectations are substantially affected by the dominant values of the society.

The other independent variables in the regression do not appear as explanatory, predictive variables, although they have high association with the dependent variable. This may be due to two reasons: First, these apparently non-predictive variables, political participation, civil liberties and happiness, are difficult to measure and partly subjective variables which may not reflect the true reality. Second, PISA score in reading ability may be an incorrect measure of educational achievement.

\section{References}

Acemoğlu, D., Johnson, S., Robinson, J. A., \& Yared, P. (2005). From Education to Democracy? The American Economic Review, 95(2), 44-49. https://doi.org/10.1257/000282805774669916

Adedeji, S. O., \& Bamidele, R. O. (2003). Economic Impact of Tertiary Education on Human Capital Development in Nigeria. Selected papers for the 2002 Annual Conference. Nigerian Economic Society (NES). Ibadan. Polygraphis Ventures Ltd.

Barro, R. J. (1999). The Determinants of Democracy. Journal of Political Economy, 107(6), 158-183. https://doi.org/10.1086/250107

Bertschy, K., M. Cattaneo M. A., \& Wolter, S. C. (2009). PISA and transition into the labor market. Labor 23, 111-123. https://doi.org/10.1111/j.1467-9914.2008.00432.x

Blanchflower, D. G., \& Oswald, A. J. (1994). Estimating a wage curve for Britain 1973-90. The Economic Journal, 104(426), 1025-1043. https://doi.org/10.2307/2235062

Boateng, K. (2002). Higher education and the labour market: a logical framework for policymakers in Africa's education sector. Draft. Addis Ababa: Economic Commission for Africa. (18).

Bourguignon, F. (2005). Equity and economic growth: Permanent questions and charging. Answers, prepared for Human Development Report, UNDP.

Bowles, S., \& Herbert, G. (1976). Schooling in Capitalist America: Education Reform and the Contradictions of Economic Life (pp. 131-132). New York: Basic Books Inc.

Castriota, S. (2006). Education and happiness: a further explanation to the easterlin paradox? CEIS Working Paper No. 246.

Dewey, J. (1916). Democracy and education. New York: Macmillan.

Fischer, J. A. (2007). The impact of direct democracy on public education: evidence for Swiss students in reading, mathematics and natural science (No. 688). SSE/EFI Working Paper Series in Economics and Finance.

Frey B. S., \& Stutzer, A. (2002). Happiness \& economics. Princeton: Princeton University Press.

Giddens, A. (2000). Runaway world: How globalization is reshaping our lives. New York: Routledge.

Glaeser, E. L., La Porta, R., Lopez-de-Silanes, F., \& Shleifer, A. (2004). Do institutions cause growth? Journal of Economic Growth, 9, 271-303. https://doi.org/10.1023/B:JOEG.0000038933.16398.ed

Glaeser, E. L., Ponzetto, G., \& Sheifer, A. (2006). Why does democracy need education? NBER Working Paper, http://www.nber.org/papers/w12128

Glewwe, P., \& Jacoby, H. G. (2004). Economic growth and the demand for education: is there a wealth effect?. Journal of Development Economics, 74(1), 33-51. https://doi.org/10.1016/j.jdeveco.2003.12.003

Hadenius, A. (2006). Transitions to democracy: pros and cons of the Rustow-Lijphart elite appoach. In O. Elgström \& G. Hyden (Eds.), Development and democracy- what have we learned and how? New York: Routledge-ECPR.

Helliwell, J., Layard, R., \& Sachs, J. (2017). World happiness report 2017. Retrieved from $\mathrm{http}: / /$ worldhappiness.report/wp-content/uploads/sites/2/2017/03/HR17.pdf 
Huntington, S. P. (1993). The third wave: Democratization in the late twentieth century. Oklahoma: University of Oklahoma Press.

Karasar, N. (2006). Bilimsel araştırma yöntemleri. Ankara: Nobel.

Lipset, S. M. (1959). Some Social requi-sites of democracy: Economic development and political legitimacy. American Political Science Review, 53(1), 69-105. https://doi.org/10.2307/1951731

Michalos, A. C. (2007). Education, happinnes and well-being. International Conference on "Is happinnes measurable and what do those measures mean for public policy" (Roma, Italy, 2-3 April 2007).

OECD. (2016). PISA 2015. Retrieved from https://www.oecd.org/pisa/pisa-2015-results-in-focus.pdf

Omoniyi, M. B. I. (2013). The role of education in poverty alleviation and economic development: a theoretical perspective and counselling implications. British Journal of Arts and Social Sciences, 15(II).

Papaioannou, E., \& Siourounis, G. (2008). Economic and social factors driving the third wave of democratization. Journal of Comparative Economics, $36,387$. https://doi.org/10.1016/j.jce.2008.04.005

Porter, M. E. (1990). The comparative advantage of nations. New York: The Free Press. https://doi.org/10.1007/978-1-349-11336-1

Psacharopoulos, G. (1998). Returns to investment in education: A global Update. World Development, 22(9), 101-110.

Roberts, L. (2011). Mechanics of economic development. Journal of Monetary Economics, 22(1), 202-209.

Romer, P. (1990). Endogenous technological change. Journal of Political Economy, 98, 71-102. https://doi.org/10.1086/261725

Roskin, M. G. (2007). Countries and concepts: Politics, geography, culture. New Jersey: Pearson Prentice Hall.

Rustov. D. (1970). Transitions to Democracy. Comparative Politics, 2(3).

Saint, W., Hartnet, T., \& Strassner, E. (2003). Higher education in Nigeria: A status report. Higher Education Policy, 16, 259-281. https://doi.org/10.1057/palgrave.hep.8300021

Shultz, T. (1961). Education and economic growth. In N. B. Henry (Ed.), Social forces influencing American, education. Chicago: National Society for the Study of Education, University of Chicago Press.

Shultz, T. (1988). Education investment and returns. In (Ed. Chenery H. and Srinivasan T.) Handbook of Development Economics. North Holland.

The Economist Intelligence, Unit Limited. (2016). Democracy index 2015: Democracy in an age of anxiety. Retrieved from https://www.yabiladi.com/img/content/EIU-Democracy-Index-2015.pdf

Tocqueville, A. (1848). Democracy in America. (Trans. G. Lawrence; ed. J. P. Mayer). New York: Harper and Row.

United Nations Development Programme. (2016). Human development report 2016: Human development for everyone. Retrieved from http://hdr.undp.org/sites/default/files/2016_human_development_report.pdf

Varsakelis, N. C. (2006). Education, political institutions and innovative activity: A cross-country empirical investigation. Research Policy, 35(7), 1083-1090. https://doi.org/10.1016/j.respol.2006.06.002

Weber, M. (1930). The protestant ethic and the spirit of capitalism. New York, NY: Harper Collins.

Wolfe, T. (1997). Multi-models of quality education. Educational Review, 5(1), 88-96.

\section{Appendix A}

\begin{aligned} & \hline Countries \\ & \hline 1. Singapore \\ & 2. Japan \\ & 3. Estonia \\ & 4. China \\ & 5. Finland \\ & 6. Canada \\ & 7. Vietnam \\ & 8. Hong Kong - China \\ & \hline\end{aligned}


9. South Korea

10. New Zealand

11. Slovenia

12. Australia

13. United Kingdom

14. Germany

15. The Netherlands

16. Switzerland

17. Ireland

18. Belgium

19. Denmark

20. Poland

21. Portugal

22. Norway

23. United States

24. Austria

25. France

26. Sweden

27. Czech Republic

28. Spain

29. Latvia

30. Russia

31. Luxemburg

32. Italy

33. Hungary

34. Lithuania

35. Croatia

36. CABA-Argentina

37. Iceland

38. Israel

39. Malta

40. Slovak Republic

41. Greece

42. Chile

43. Bulgaria

44. United Arab Emirates

45. Uruguay

46. Romania

47. Cyprus

48. Moldova

49. Albania

50. Turkey

51. Trinidad and Tobago

52. Thailand

53. Costa Rika

54. Qatar

55. Colombia

56. Mexico

57. Montenegro

58. Georgia

59. Jordan

60. Indonesia

61. Brazil

62. Peru

63. Lebanon

64. Tunis

65. Macedonia

66. Algeria

67. Dominic Republic 


\section{Copyrights}

Copyright for this article is retained by the author(s), with first publication rights granted to the journal.

This is an open-access article distributed under the terms and conditions of the Creative Commons Attribution license (http://creativecommons.org/licenses/by/4.0/). 